\title{
TECHNOLOGY-BASED TEACHING MATERIAL DEVELOPMENT TRAINING FOR PRE-SERVICE TEACHERS TO IMPROVE STUDENTS' LEARNING OUTCOMES
}

\author{
Zulfah Fakhruddin ${ }^{1}$, Amzah $^{2}$, Nur Fadillah Nurchalis ${ }^{3}$ \\ IAIN Parepare, Jl. Amal Bhakti No.8, Bukit Harapan, Soreang, Parepare, Sulawesi Selatan 91131 \\ fakhruddin.zulfah@yahoo.com ${ }^{1}$, selle.amzah@gmail.com², nurfadillahnurchalis@yahoo.com ${ }^{3}$
}

\begin{abstract}
This research aimed to examine the effectiveness of technology-based English teaching material development training to improve students' learning outcomes. This research used quasi-experimental design. The instrument of this research was a multiple-choice test. In collecting data, the writers applied pre-test, treatment, and post-test to students. There were four pre-service teachers who involved in the treatment of this research. Two of them taught in experimental classes and the other two taught in control classes. Pre-service teachers who taught in experimental classes had been trained for ten meetings, while those who taught in control classes had not been trained. This research used SPSS 17 to analyze the data. The result of this research found that there was significant difference of students' learning outcomes between experimental and control classes after having the treatment. Students' learning outcomes in experimental classes was higher than in control classes. The effect size of significant level after calculated by Eta squared was 0,042. Event though it had small effect, the technology-based English teaching material training given to the pre-service teachers was quite effective to improve students' learning outcome in MTs Negeri Parepare
\end{abstract}

Keywords: Training; Technology; Material Development

DOI: $10.15642 /$ NOBEL.2019.10.1.87-102

Teaching materials are the resources used by teachers to perform pedagogical activities. The resources include printed and non-printed versions like digital textbooks, CDs, Maps, and Videos. To meet students' needs and wants, teachers should evaluate the teaching materials, and then develop them. Tomlison (2010) states that no single textbook can accommodate students' needs and wants perfectly. Therefore, teachers are in charge persons to evaluate, adapt, replace, and revise the materials. In other word, teachers are teaching material developers, they can modify printed to online materials and vice versa. Teachers have power and freedom to develop their teaching materials as long as they do not deviate from the designated curriculum.

Modern technology is inevitable in the current situation of education. It has great possibilities to cover variety of students' learning styles. The more modern a 
technology, the more helpful it is for supporting the teaching and learning process. With regards to material development, teachers are expected to be able to apply or integrate technology for their teaching materials development.

During instructional process in the classroom, Kitao (1997) finds how teachers only rely on textbook heavily. Solihin in Wurinanda (2018) also states that teachers generally still use conservative ways in teaching, even though educational technology in this digital era has greatly developed. Results from a survey revealed that only a few of 151 science teachers from Java, Bali, Sulawesi, Maluku and Papua had access to learning websites regularly. Suminto (2012) finds that most of them rely only on the searching machine like Google and the use of other advanced technology to support and develop their teaching materials is still poorly explored.

As a matter of fact, it is undeniable that students are now truly engaged with their smart phones not only to access information but also to involve themselves in virtual activities. Students use their electronic devices in almost all their daily activities, not to mention in their own learning situation. That said, teachers should initiate to integrate technology in their classroom activities in order to accelerate their teaching and meet the needs of their students to use their gadgets to support the learning process. Teachers should develop materials through various technologybased innovations, so that it will reduce monotonous activities in the classroom.

However, several teachers face problems in developing their teaching materials. Mirizon and Yunus (2008) find that there are five causes of difficulties faced by English teachers in developing their teaching materials. Some of the problems are: minimum training or socialization for the teachers about the applied curriculum, lack of insightful knowledge of how to develop appropriate teaching materials, and minimum support from their schools, either financial or non-financial.

Another research (Sikki et al., 2013) suggests that professional development for English teachers in primary schools is necessarily needed to create a better education. In so doing, teachers should be encouraged and boost themselves to participate in seminars, workshops, and trainings in order to broaden their knowledge and improve their competence as professional language teachers. By participating in such activities, teachers not only get improved knowledge but also raise their confidence as professional English teachers.

Knowing proper and better instructions for language teaching is also mandatory for new teachers. They need to gain enough knowledge and real experience through 
trainings, seminars, or conferences on how to handle their classes properly. Nevertheless, such trainings are barely held by schools or other educational institutions for pre-service teachers. The trainings are more often designed and dedicated for in-service teachers rather than for pre-service teachers. This is due to false assumption that in-service teachers' trainings are compulsory, while those for pre-service teachers are not compulsory. Streven (1977) argues that excellent and valuable language teaching trainings followed by pre-service teachers could be wonderful experiences and a good starting point for the new teachers before getting into their real profession as language teachers.

Teachers' training should be done earlier for pre-service teachers before they step into their real classrooms. This is significant to prepare the future teachers so that they are ready and have adequate knowledge and motivation to run and keep going on with their own classes in the near future. Lingam et al. (2014: 2134) states "Teachers' ability to meet the complex and challenging demands of work successfully depends on their professional preparation." This is to imply that preservice teachers' training is a part of essential preparation for new teachers to get ready into their career as professional teachers.

To cope with such challenge, this research focuses on technology-based training for pre-service teachers. New experiences through training will inspire preservice teachers to expand themselves, especially for the sake of meeting with the millennial students' behaviors. This is in line with the result of a survey conducted by an educational technology company stating that technology has indeed played a significant role in education. Schramm (2015) states that $78 \%$ of students frequently read their course materials with a device. This percentage is up from $48 \%$ of students who read their course materials from digital devices in 2011.

Pre-service teachers here are students in the final year of bachelor degree of English Education department at IAIN Parepare. The training prepared for them was focused on exploring the use of technology to develop English teaching materials. The training concerned with some topics like publishing sites, presentation software, exercise-creating tools, moviemaker and podcasting. Pre-service teachers were required to design one material that they were going to use to teach. And for the effectiveness of pre-service teachers' material development was measured through students' outcome. Substantially, this research explored the effectiveness of 
technology-based training for pre-service teachers to develop English teaching materials.

\section{REVIEW OF LITERATURE}

Some researchers have studied the use of technology in education and its roles in developing teaching materials. Achmad (2017) finds that there is a positive and significant relationship between the development of teaching materials and the use of media. The result shows that students' learning outcome in Islamic Religious Education in public elementary school Sungai Kunjang has improved significantly. In developing English teaching materials, media play an important role to support the implementation of teaching materials development. Rondon and Vera (2016) discuss that teachers need to implement a pedagogical intervention in their classroom. This can be done by integrating the four language skills through different forms of teaching materials, promoting interactive learning through online resources, and using course books to have natural and global English exposure.

Similar research about teaching materials development was also conducted by Mujiono (2012). He reveals that after developing multisensory-based teaching materials, the effectiveness of learning English for elementary school students is getting better than using previous normal or conventional materials. Integrating various forms of teaching materials and different kinds of media create multisensory materials, and it makes the learning more effective.

With regard to pre-service teachers' training, Amalia (2014) studied about the perspective of pre-service teachers toward Genre Based Approach for English language teaching find something. She reveals that Genre Based Approach has not been explored yet in terms of giving adequate preparation for pre-service teachers to have better performance in language skills. Hence, she recommends that preservice teachers' trainings on English language teaching and material development are needed to be done. She deliberately states that such trainings are important to help new teachers preparing and planning their lessons for their students. Amalia's research encourages the writers to conduct a research related to pre-service teachers' preparation in developing their English teaching materials.

This current research is therefore inspired by the previous research on how the use of teaching media play significant role in developing English teaching materials. The focus of this research is on technology-based training, especially the use of 
teaching media for the new teachers to develop their teaching materials. Technology-based training in this research is intended to develop teaching materials by integrating different forms of teaching materials to create interactive learning in the classroom.

According to Brown (1995), material is any systematic description of the techniques and exercises to be used in classroom teaching. Materials have wellordered procedures to ease teachers to teach and evaluate. Teaching materials aim to help students learn something, provide various types of teaching material choices, facilitate teachers in carrying out learning, so that learning activities become more interesting.

In terms of language learning, Tomlison (1998) defines that material denotes anything used by teachers and learners to facilitate language learning. It can be concluded that teaching materials in language classroom are the resources which assist language teachers to deliver instruction such as course books. Woodward (2001) mentions that course books include not only textbook and workbook, but also recording and other materials offered in a package from publishers. The course book aims to point out the lesson and to assess students' achievement to the lesson.

Cakir (2015) classifies instructional materials into three groups. The first is traditional materials, such as course book, workbook, teachers' guidance, chart, flashcard, teacher-made materials etc. The second is audio and visual materials, such as video player, audio player, projection device, computer, etc. The third is information communication technologies (ICT) based materials, such as interactive white boards (IWB), materials providing mobile assisted language learning (MALL), tablets, computers, podcasts, smart phone, and the Internet.

There are many commercial teaching materials available in the bookstores, yet this does not necessarily mean that teachers must rely on them the whole time during their teaching. To meet with students' needs, teachers should develop their own materials; they can function as the innovators and developers in their own classroom. They are allowed to design what is needed in their classroom by firstly conducting the need analysis for their students. It is not recommended for the teachers to merely follow and use the accessible teaching materials without considering their students' need. The instructional process in the classroom could be meaningless and pointless as some students may understand the materials, and some may not. 
Grant (1987) defines that material development is anything done by material developers or teachers to help language learning. To develop a teaching material, teachers play essential roles and have to do some sequence of activities, such as sorting and evaluating the teaching material whether it is suitable or not, finding and knowing students' learning styles, and identifying students' strengths and weaknesses in learning. Afterwards, teachers can choose what materials are in line and applicable with the syllabus in their schools. Teachers, then, decide whether they will adapt, replace, omit, or add materials used from the chosen textbooks.

In terms of technological literacy, Hyland (2003) argues that even though teachers are quite familiar with the use of social media such as Facebook, Friendster, and the like, this does not necessarily mean that they are techno literate. Teachers may not be able to operate or use other advanced technology, tools or applications specifically designed for language learning and teaching. Therefore technology-based training for language teachers is indispensable to help teachers get ready and familiar with existing technology for their teaching. Sharma (2009) says that the role of teacher together with the role of technology can lead to advance learning results.

Technology contributes greatly to the world of education. However, teachers are not all ready and familiar with the use of advanced technology to support their teaching process. Some teachers still however face serious barriers and difficulties when it comes to applying and implementing technology in their classroom. Johnson, Jacovina et al. (2016) claim that there are at least two factors that hamper teachers to incorporate technologies in the classroom, that is external and internal factors. The external factors are access, resources, training, and support, while the internal factors are teachers' attitudes and beliefs, resistance toward technology in the classroom, and their lack of knowledge and skills in language teaching and learning.

When a school has high-tech computing devices, but it does not have capable human resources to operate them properly, the implementation of computer use in learning is not feasible. Computers only become accessories. Ertmer et al. (1999:61) says, "The most commonly cited reason for lack of technology implementation in the classroom is inadequate professional development and training". Every year technology always develops, and changes constantly. If a teacher in the school is not updated with the development of technology for language teaching and learning, then the teaching and learning process stay the same as that in the old age, nothing 
changes. Teachers be it new or old teachers are hence demanded to develop their professionalism through technology-based training.

In language teaching, Erben et al. (2009) uses a specific term e-creation tools for technology applied in teaching. E-creation tools are software or application of software that provide a free forum for students to publish their original work. They can function as media to help language learning more interactive, efficient and effective. They are purposefully designed to construct activities that maximize opportunities for English language learners to interact with each other in English. There are five kinds of e-creation tools. They are web publishing sites, presentation software, and exercise creating tools, movie maker and podcasting. These tool are all applicable for English teaching and learning.

Pre-service teachers as future teachers have to prepare their readiness to face real challenges of teaching environment at schools. Pre-service teachers have a key role in preparing future teachers to deliver effective education. To achieve good education, it requires good teachers. Good teachers are experienced teachers. To produce good teachers, there should be careful preparation in which provides high quality pre-service teacher training or education. The training is offered for them to upgrade their knowledge, skills, and experiences throughout their career ahead.

Hoseanto et al. (2014) findthat training for pre-service teachers has good impact. Pre-service teachers felt more prepared as teachers upon completion of their training. They also become more confident to face the class.

The theoretical framework underlying in this research is shown in the following diagram: 


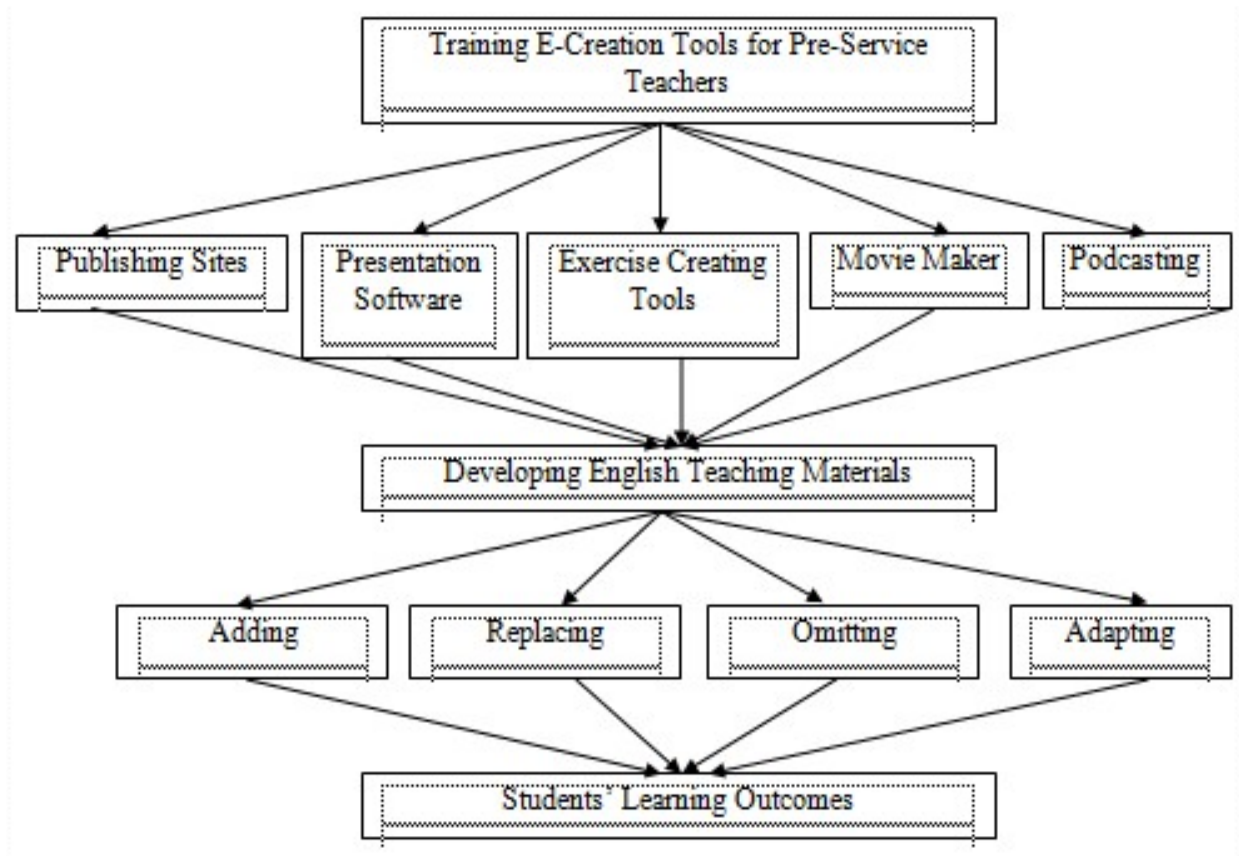

Figure 1: Theoretical Framework

Input : Pre-service teachers are divided into two groups. Trained and non-trained pre-service teachers. Both groups have known theories about English Material Development as they learnt it in their regular class at campus.

Process : Treatment means training for pre-service teachers who will teach at experimental classes about how to integrate technology in developing English teaching materials. The technology training covers E-creation tools, namely publishing websites, presentation software, exercise-creating tool, moviemaker, and podcasting. They add, replace, omit, or adapt the material based on students' needs and wants. For non-trained pre-service teachers, they develop their teaching materials based on their previous knowledge and experiences gained at their campus.

Output : After having the process, the effectiveness of training is measured by looking at the students' learning outcome 


\section{METHODS}

This research used quasi-experimental design. The population of this research was 180 students of MTs Negeri Parepare classified into six classes (VII.1 to VII.6). The samples were taken by using cluster random technique from four classes with total number of the students is 120 . They were put in four different classes: VII.2, VII.3, VII.4, and VII.5. Two of them (VII.2 and VII.3) were experimental classes and the rest (VII.4 and VII.5) of them were control classes. Data collection was taken from pretest, treatment, and post-test.Pre-test was administered to find students' prior learning outcome. The researchers gave a multiple choice test consists of fifty items. After that there were different treatment for both experimental group and control group given by the preservice teachers.

There were four pre-service teachers involved in this research. Two of them taught in experimental classes and the other two taught in control classes. The preservice teachers who taught in experimental classes had been trained for ten meetings. The training materials given to them were publishing sites, presentation software, exercising tools, moviemaker, and podcasting.

In experimental group, treatments were given by trained pre-service teachers. Each of the pre-service teachers was allowed to decide and develop their own English teaching materials that appropriate for their students. They were also permitted to consider which media were suitable to be used and employed in developing their teaching materials. They should considerably take into account what they had learned and gained during the training.

Meanwhile, treatments were given by non-trained pre-service teachers to their students. Each of the pre-service teachers were also allowed to develop their English teaching materials based on their previous experiences during their studies. In this phase, the researchers did not give any intervention into what and how the non-trained pre-service teachers had to do with their class.

Both experimental group and controlled group had four meetings for the treatments. In the first and the second meeting, pre-service teachers taught listening skill in the level of literal listening and pre-listening comprehension. In the third and the fourth meeting, preservice teachers taught literal reading and pre-reading comprehension.

Post-test was administered to find out students' achievement in their learning outcome. This test aimed to observe and measure any changes of the students listening comprehension after being taught by both trained and non-trained pre-service teachers. The test given in the post-test was similar to what the students had in the pre-test. The instrument of this 
research was a multiple-choice test consisted of 50 item questions. The data were analyzed using SPSS 17 and Eta squared formula was employed to classify the effect size of significant differences.

\section{RESULTS AND DISCUSSIONS}

Before going further into data analysis, the researchers did normality test using statistic analysis as a requirement to conduct parametric analysis. It aimed to know whether the data of this research were normally distributed or not. Here is the result of the normality test.

Table 1. Normality test

\begin{tabular}{lcc}
\hline \multicolumn{1}{c}{ Variables } & Skewness & Kurtosis \\
\hline Pre-test Experiment \& Control class & 0,111 & $-0,817$ \\
\hline $\begin{array}{l}\text { Post-test Experiment \& Control } \\
\text { class }\end{array}$ & 0,064 & $-0,717$ \\
\hline
\end{tabular}

Based on the Skewness (pre-test $=0,111$; post-test $=0,064$ ) and Kurtosis (pretest $=0,017$; post-test $=0,717$ ) analysis, the data is between intervals -2.00 to 2.00 . It means that the data of this research are normally distributed, so parametric analysis can be used. Parametric analysis used in this research is independent and dependent t-test. Another requirement of a parametric analysis is homogeneity test. Here is the result of homogeneity test.

Table 2. Homogeneity test

\begin{tabular}{|c|c|c|c|}
\hline \multicolumn{4}{|c|}{ Independent Samples Test } \\
\hline & & \multicolumn{2}{|c|}{ Levene's Test for Equality of Variances } \\
\hline & & $\mathbf{F}$ & Sig. \\
\hline \multicolumn{2}{|c|}{ pre_basing Equal variances assumed } & 4.993 & .027 \\
\hline & $\begin{array}{l}\text { Equal variances not } \\
\text { assumed }\end{array}$ & & \\
\hline post_basin & Equal variances assumed & .962 & .329 \\
\hline g & $\begin{array}{l}\text { Equal variances not } \\
\text { assumed }\end{array}$ & & \\
\hline
\end{tabular}

Based on the data from the table, the obtained value of $\mathrm{F}=4.993$ and $\mathrm{Sig}=$ 0.027 . It shows that the pre-test data in the experimental and control classes are not homogeneous (in which Sig <0.05). Although it is not homogeneous, the determination of t-test can use Equal variances not assumed. For the post-test data in the experimental class and the control are homogeneous (in which Sig> 0.05), the determination of the value of $t$ uses Equal variances not assumed. Normality test and 
homogeneity test aims to fulfill the requirements to use parametric analysis test, that is dependent and independent t-test.

Before analyzing the significant difference of pre-test between experimental class and control class, we should know the mean score of the two classes as shown in the following table: 
Table 3. Mean score of pre-test between experiment and control class

\begin{tabular}{llcc}
\hline & Group & Mean & SD \\
\hline Pre-test & Experiment & 40.5161 & 16.27201 \\
\cline { 2 - 4 } & Control & 41.8966 & 13.16786 \\
\hline
\end{tabular}

Table 3 shows that in the pre-test, control class has higher mean score $=41.89$; $S D=13.16$ than experiment class (mean $=40.51 ; S D=16.27$ ). The difference is only very slight, so it can be concluded that the ability of students in the beginning of this research is almost the same. To see the significance level of difference of pre-test between experiment and control class, we can look at the following table.

Table 4. Significance of pre-test between experiment and control class

\begin{tabular}{|c|c|c|c|c|c|c|}
\hline & & \multicolumn{2}{|c|}{$\begin{array}{c}\text { Levene's Test } \\
\text { (Homogenity Test) }\end{array}$} & \multicolumn{3}{|c|}{$\begin{array}{l}\text { Test of Significant } \\
\text { difference }\end{array}$} \\
\hline & & $F$ & Sig. & $t$ & Df & Sig \\
\hline \multirow{2}{*}{$\begin{array}{l}\text { Pre-test of } \\
\text { experiment } \\
\text { and controlled } \\
\text { class }\end{array}$} & $\begin{array}{l}\text { Equal } \\
\text { variances } \\
\text { assumed }\end{array}$ & 4.993 & .027 & -.509 & 118 & .612 \\
\hline & $\begin{array}{l}\text { Equal } \\
\text { variances not } \\
\text { assumed }\end{array}$ & & & -.512 & 115.647 & .609 \\
\hline
\end{tabular}

Table 4 indicates that the data of pre-test between experimental and control class are not homogenous $(\mathrm{F}=4.993 ;$ Sig<0.05). Therefore, to conduct test of significant difference, it uses equal variance not assumed. It shows that there is no significant difference of students' learning outcome in pre-test between experimental and control classes $(t=0.512 ;$ Sig $>0.05)$. It means that students' ability both experimental and control classes before given treatment are same.

After having treatments to both experimental and control classes, here is the result of students' learning outcome in post-test.

Table 5. Description of mean score of post-test between experimental and control classes

\begin{tabular}{llrr}
\hline & group_post & Mean & SD \\
\hline Post-test & Experiment & 54.064 & 12.6541 \\
& & 5 & 3 \\
\cline { 2 - 4 } & Control & 49.034 & 11.3647 \\
& & 5 & 1 \\
\hline
\end{tabular}

Table 5 shows that in the post-test, experimental class has higher mean score= 54.06; $\mathrm{SD}=12.65$ than control class (mean $=49.03 ; \mathrm{SD}=11.36)$. The difference is 
significant, so it can be concluded that the students' learning outcome in experimental class is higher than in control class. It indicates that treatment given by trained pre-service teachers was effective to improve students' learning outcome than treatment given by non trained pre-service teachers. It proves that technologybased English material development training given to pre-service teachers contributes positive effects to students' learning outcome.

To know the significance level of difference of post-test between experiment and control class, have look at the following table.

Table 6. Significance of student' learning outcome in post-test between experimental and control classes

\begin{tabular}{|c|c|c|c|c|c|c|}
\hline & & \multicolumn{2}{|c|}{$\begin{array}{l}\text { Levene's Test for } \\
\text { Equality of } \\
\text { Variances }\end{array}$} & \multicolumn{3}{|c|}{ Test of Significant difference } \\
\hline & & $\mathrm{F}$ & Sig. & $\mathrm{T}$ & Df & Sig. (2-tailed) \\
\hline \multirow[t]{2}{*}{$\begin{array}{l}\text { post_basin } \\
g\end{array}$} & $\begin{array}{l}\text { Equal variances } \\
\text { assumed }\end{array}$ & .962 & .329 & 2.285 & 118 & .024 \\
\hline & $\begin{array}{l}\text { Equal variances } \\
\text { not assumed }\end{array}$ & & & 2.294 & 17.810 & .024 \\
\hline
\end{tabular}

Based on the table 6, it can be stated that the data are homogenous $(F=.0962$; Sig $>0.05$ ). Therefore, to conduct test of significant difference, it uses Equal variances assumed. It shows that there is a significant different of students' learning outcome in post-test between experimental and control classes $(t=2.285$; Sig<0.05). It indicates that students' learning outcome between experiment and control classes after having treatment is different. To know the effect size of significant level, the researchers calculate the data using Eta Squared formula as follow:

EtaSquared $=\frac{t^{2}}{t^{2+i 6} i}$

in which:

$$
\begin{array}{ll}
1.1 & =\text { small effect } \\
0.06 & =\text { moderate effect } \\
0.16 & =\text { large effect (Cohen, 1998) }
\end{array}
$$

The result of the calculation is 0.042 , means that the effect size of significance is small. This can be said that the difference of students' learning outcome between students in experimental and control class was not significant. It means that there were no any differences among 120 students who had been as samples in this research. In the beginning of this research, all students had almost similar ability in 
English. Therefore, treatments from pre-service teachers in both classes truly influenced their final outcome.

The participants of this research were students who had been classified properly by the school into four classes based on their abilities. There were two classes that researchers did not take as samples in this research: class VII.1 and VII.6. In the preliminary observation before conducting this research, the researchers identified the students by interviewing the English teachers at that school. Based on their statements, they said that the two classes were different from the four classes. Students in class VII.1 were skillful students, while students in class VII.6 were unskillful students. The decision to choose those four classes was considerably appropriate. It supported a pure quasi-experimental design of this research. This also indicates that both the students and the teachers can learn and keep their English skills balance during the learning and teaching process at that school.

A research conducted by Price (1998) suggests that pre-service teachers could do better after they have given a chance to practice educational theories. In a similar opportunity, pre-service teachers can practice and employ educational theories that they have for their students at schools. The trained pre-service teachers developed materials based on what they had during the training, while the non-trained preservice teachers developed materials based on what they gained during studying at campus.

The trained and non trained pre-service teachers had different performances in the classroom. The performances of trained pre-service teachers granted different impact to students' learning outcome. It shows the positive power of technologybased training for pre-service teacher as it could upgrade their ability to develop English teaching materials. It also contributes to the improvement of students' learning outcome.

When teaching listening skills in experimental classes, pre-service teachers taught their students by adding some audiovisual materials, such as videos. They made the audio by themselves. In contrast, pre-service teachers in control classes only taught by pronouncing some words manually. When teaching reading skills in experimental class, pre-service teachers taught by adapting a new reading text in several slides, while in control classes, pre-service teachers taught only by using available reading text in the course book. In administering a test, pre-service 
teachers in experimental classes used quiz creator, while in control class, preservice teachers only relied on the exercises available on the course book.

When the pre-service teachers integrated technology to develop their English teaching materials, students' learning outcome was getting better. Sudjana (2002) found that $76.6 \%$ of student learning outcomes were affected by teacher performance. Teachers as the main actors of the class deserve to determine their own plans. Therefore, a decision taken by pre-service teachers to integrate technology in their English material development is a good choice. Technology integration by pre-service teachers played roles in significant difference of the two classes.

Thieman (2016) states that for few years, leaders and researchers in technology use have been criticizing teacher education programs for inadequately preparing pre-service teachers to integrate technology into their instructional materials with their students. This statement is relevant to what happened in this research. Non-trained pre-service teachers in control class did not integrate technology in developing their English teaching material. It happened because they are lack of knowledge and experience of how to use and integrate technology for developing English teaching materials. It is different from what have obtained by the pre-service teachers who had been trained to use technology to enhance and support their teaching. It is obvious that technology-based training can elevate the quality of pre-service teachers to help and guide them in developing English teaching materials for their students.

However, the effect size of significance level in this research shows that technology-based training is not really influential to improve students' learning outcome since the effect size was considered low. The training which covered five topics include publishing site, presentation technique, exercising tools, moviemaker, and podcasting was not enough as it was conducted and run in short and limited time. It would be better if the training itself could be done in a longer time with intensive meeting for each topic to gain best results. The sufficient time devoted to the technology-based training is expected to have big influence to pre-service teachers' readiness in modifying, mixing, substituting, omitting, and adding English teaching materials.

\section{CONCLUSION}


Both trained and non-trained pre-service teachers could develop their English teaching materials for their classes. The trained pre-service teachers developed their teaching materials by integrating technology, while the non trained pre-service teachers developed their teaching materials in conventional ways. Results of this study reveal that students' learning outcome in both experimental and control class increased significantly. The results also show that there was a substantial difference between students' learning outcome in experimental and control class. Students' learning outcome in experimental class was higher than students' learning outcome in control class. It indicates that technology-based training helps pre-service teachers to develop their English teaching material. It is apparent that teaching materials developed by integrating appropriate technology for language learning are effective to improve students' learning outcomes.

Regarding to the effectiveness of technology-based training for new teachers, the researchers finally come up with the following suggestions to support this results of the study. The first is addressed to the policy makers at the faculty level; they should allocate adequate budget to provide and facilitate pre-service teachers with technology-based training. Such training is required for the new teachers so that they are ready and have high confidence to face their professional career as English teachers. The second suggestion is for the pre-service teachers themselves. Even though the faculty might not be able to provide them with technology-based training, they should have an initiative to upgrade their knowledge and competence of technology-based language learning to support their professional development. They may join similar workshop or training on technology-based language teaching and learning out of their faculty or campus.

\section{REFERENCES}

Andi, A. (2017) Hubungan pengembangan bahan ajar dan media pembelajaran dengan hasil belajar siswa pada mata pelajaran pendidikan agama Islam di Sekolah Dasar Negeri Kecamatan Sungai Kunjang. Syamil Journal Vol.5, No.1, 2017

Amalia, L.L. (2014) Genre-based approach and pre-service teachers in ELT: A Perspective. Lingua Scientia Jurnal Bahasa Vol.6, No.2, November 2014, p.223-233

Brown, D.J. (1995). The elements of language curriculum: A systematic approach to curriculum development. Boston: Heinle and Heinle. 
Cakir, Ismail. (2015). Instructional materials commonly employed by foreign language teachers at elementary schools. International Electronic Journal of Elementary Education, 2015, 8(1), 69-82 ISSN: 1307-9298 www.iejee.com

Cohen, J. (1988). Statistical power analysis for the behavioral sciences (2nd ed.). Hillsdale, NJ: Erlbaum.

Erben et all. (2009). Teaching english language learners through technology. NY: Routledge.

Ertmer, P.A.,(1999). Addressing first and second order barriers to change: strategies for technology integration. Educational Technology Research and Development, 47(4), 47-61.

Grant, N. (1987). Making the most of your textbook. NY: Longman.

Hoseanto, O., Matakupan, S.J., Yulianti, K., Margono, S., and Widanti, C.I.. (2014 December) Impact of pre-service teacher training: A case study of teacher education programme in Indonesia, retrieved from URL: https://www.researchgate.net/publication/237541323.

Hyland, K. (2003). Second language writing. Cambridge: Cambridge University Press.

Johnson, A. M., Jacovina, M. E., Russell, D. E., \& Soto, C. M. (2016). Challenges and solutions when using technologies in the classroom. In S. A. Crossley \& D. S. McNamara (Eds.) Adaptive educational technologies for literacy instruction. New York: Taylor \& Francis. Published with acknowledgment of federal support.

Kitao, K. (1997). Selecting and developing teaching/learning materials. The Internet TESL Journal, Vol.IV, No.4, April 1997. Retrieved in March 2018 from http://iteslj.org/Articles/Kitao-Materials..html.

Lingam, G., Lingam, N., and Raghuwaiya, K. (2014). Professional development of pre-service teachers: The case of practicum case. World Academy of Science, Engineering and Technology International Journal of Humanities and Social Science Vol:8,No:7,2014.

Mirizon, S. and Yunus, M. (2008). Kesulitan dalam pengembangan dan penulisan materi ajar bahasa inggris dalam menerapkan kurikulum tingkat satuan pendidikan. Forum Kependidikan Vol.28, No 1, September 2008.

Mujiono. (2012). Model pengembangan bahan ajar bahasa inggris berbasis pendekatan multisensori pada siswa sekolah dasar. Lingua Scientia, Jurnal Bahasa Vol.4, No.1, Juni 2012.

Price, B. (1998). The importance for preservice teachers to have practice experiences to apply theory to reality .Electronic Journal of Science Education. Vol. 2 No 3. Retrieved in April 25, 2018 from http://ejse.southwestern.edu/article/view/7583/5350.

Rondon, E.J.C. and Vera, L.F.V. (2016) Understanding the role of teaching materials in a beginners level english as a foreign language course: A case study. Profile Vol.18, No.2, July-December 2016. 
Sharma, P. 2009. Controversies in using technology in language teaching. Retrieved April 25, 2018 from http://www.teachingenglish.org.uk/articles/controversiesusing-technology-language-teaching.

Sikki, E.A.A. et all. The competence of primary school english teachers in indonesia. Journal of Education and Practice, Vol.4, No.11, 2013. Page 139145.

Sharma, P. 2009. Controversies in using technology in language teaching. Retrieved April 25, 2018 from http://www.teachingenglish.org.uk/articles/controversiesusing-technology-language-teaching.

Strevens, P. (1977). New orientations in the teaching of english. Oxford, UK: Oxford University.

Sudjana, N. (2002). Dasar-dasar proses belajar dan mengajar. Bandung:Sinar Baru Algesindo.

Sumintono, B.. et all. (2012). Penggunaan teknologi informasi dan komunikasi dalam pengajaran: survei pada guru-guru sains di indonesia. Jurnal Pengajaran MIPA, Volume17, Nomor 1, April 2012.

Thieman, Y.G. (2016) Using technology as a tool for learning and developing 21st century citizenship skills: An examination of the nets and technology use by preservice teachers with their K-12 students. CITE Journal. Retrieved in March 28, 2018 fromhttps://www.citejournal.org/volume-8/issue-4-08/social-studies/ using-technology-as-a-tool-for-learning-and-developing-21st-centurycitizenship-skills-an-examination-of-the-nets-and-technology-use-by-preserviceteachers-with-their-k-12-students/.

Tomlison, B. (1998). Materials development in language teaching. New York: Cambridge University Press.

Tomlison, B. (2010). Materials development in language teaching, second Edition. United Kongdom: Cambridge University Press.

Woodward. T. (2001). Planning lesson and courses. Designing sequences of word for the language classroom. Cambridge: Cambridge University Press.

Wurinanda, I. (2015). Empat masalah utama pendidikan Indonesia. Retrieved in March 14 , 2018 fromhttp://news.okezone.com/read/2015/11/30/65/1258030/empat-masalahutama-pendidikan-indonesia/html. 